Citation: Kostusiak, N., Navalna, M., \& Mezhov, O. (2020). The functional-cognitive category of femininity in modern Ukrainian. Cognitive Studies / Études cognitives, 2020(20), Article 2310. https://doi.org/10.11649/cs. 2310

\section{NATALIIA KOSTUSIAK}

Lesya Ukrainka Eastern European National University, Lutsk, Ukraine https://orcid.org/0000-0002-9795-6038 nat_kostusyak@ukr.net

\section{OLEKSANDR MEZHOV}

Lesya Ukrainka Eastern European National University, Lutsk, Ukraine

https://orcid.org/0000-0002-5299-417X

mezhov@ukr.net

\section{MARYNA NAVALNA}

Pereiaslav-Khmelnytskyi Hryhorii Skovoroda State Pedagogical University, Pereiaslav, Ukraine

https://orcid.org/0000-0002-5064-3122

mnavalna@gmail.com

\title{
THE FUNCTIONAL-COGNITIVE CATEGORY OF FEMININITY IN MODERN UKRAINIAN
}

\begin{abstract}
The article describes in detail the latest feminine nouns of professions, job titles, and other activities. These nouns form part of the lexico-semantic system of Ukrainian and at the same time demonstrate its continuous dynamics. These neo-derivatives are actively used in modern Ukrainian media texts, contributing to the modernization and liberalization of the text, and to the creation of gender-linguistic balance. The need to involve feminitives in linguistic use is indicated by their codification in the new Ukrainian Orthography, although in previous editions they were ignored. These arguments and the focus on the idea of bilateral interpretation (semantics as dominant and formal), including in the context of anthropocentrism and active communication, form the basis for the development of the functional-cognitive category of femininity. Research into derivatology and semantic syntax make it possible to consider feminine personal nouns as elements with certain semantic-syntactic features, representing a profound and comprehensive aspect of the research. This is supplemented by the lexico-semantic classification of these units. The specific characteristics of Ukrainian-language names are identified by a detailed study of the means of expressing femininity - suffixes and case forms of feminine personal nouns - and their codified use. This set of features serves as the basis for the interpretation of the category of femininity as an abstract concept that generally denotes units with the meaning of feminine gender and combines three grammemes with a narrower categorical meaning: feminitive subjectivity; feminitive objectivity; and feminitive addressant, which form a certain hierarchy and semantic-cognitive paradigm.

Keywords: feminitives; Ukrainian language; functional-cognitive category of femininity; grammeme of feminitive subjectivity; grammeme of feminitive objectivity; grammeme of feminitive addressant
\end{abstract}




\section{Introduction}

Since the end of the twentieth century, linguistics has seen a significant shift of emphasis away from the formally oriented study of language towards the cognitive-anthropocentric, communicativepragmatic, psycholinguistic and other dimensions. The supporters of this trend focus their efforts primarily on the description of language units through the prism of their contextual expression in specific communication situations, considering their modificational and transpositional processes, viewing them in terms of the emotional-expressive impact on the recipient, etc. A positive feature of recent work has been the recognition of semantic priority. In particular, I. R. Vykhovanets fairly states that the defining semantic criterion indicates the deep semantic factors on which the syntactic and morphological features of words are formed (Vykhovanets', 1988, p. 13). This approach makes it possible to view linguistic signs as being formed as a result of cogitative and speech operations, peculiar conceptual reflections of objects, phenomena, and characteristics of the objective world. In addition, the advantage of the semantic model of analysis is confirmed by the classical awareness of the close relationship between language and thought and the specific functional purpose of each nomination. It is equally important to adhere to this aspect in the study of units that have only recently entered the language system. Among such units, feminitives figure prominently and their active use can now be observed in the mass media. Despite the recommendations given in the new edition of Ukrainian Orthography (Ukraïns'kyı pravopys, 2019) on the peculiarities of their creation, a number of problems have arisen, especially the inconsistent use of different suffixes. These can sometimes even include suffixes which are outside the norms of modern literary Ukrainian. In addition to word-formative codification, feminitives have been the subject of active discussion, especially regarding the relevance or irrelevance of their production. Thus, the study of women's job titles, feminine nouns based on activities, and other words in this lexico-semantic group is among the most relevant fields of study in the Ukrainian language. Therefore, the purpose of the article is the cognitive-functional, lexico-semantic and derivational study of these units, with additional commentary on their codification in the Ukrainian language system.

Feminitives have been repeatedly described by researchers in many fields and on the basis of different languages. Feminism in the context of language theory has been studied by D. Cameron (Cameron, 1992), the concept of gender linguistics has been implemented by M. Karwatowska, \& J. Szpyra-Kozłowska (Karwatowska \& Szpyra-Kozłowska, 2010), M. H. Mills (Mills, 1999), A. Weatherall (Weatherall, 2003), the issue of gender identity in the plane of discourse has been raised by L. Litosseliti, \& J. Sunderland (Litosseliti \& Sunderland, 2002). The feminine personal nouns included in modern Polish dictionaries have been analysed by Z. Kubiszyn-Mędrala (Kubiszyn-Mędrala, 2007). The peculiarities of the use of feminine nouns with the suffix $-k(a)$ in modern Russian media texts has been brought to light by R. Guzaerova, D. Sabolova, \& V. Kosova (Guzaerova et al., 2018). In Ukrainian studies, a detailed description of innovations with the importance of feminitives has been produced by A. M. Arkhangelska (Arkhanhel'ska, 2013a, 2013b, 2014a, 2014b), L. Bilaniuk (Bilaniuk, 2003), in comparison with masculinitives, which have been studied by A. A. Zagnitko (Zahnitko, 1987), O. Y. Poda (Poda, 2008), and in terms of linguoculturology - M. Y. Fedurko (Fedurko, 2010). Feminine personal nouns in Ukrainian argot have been studied by Y. Redko (Redko, 2016). An interesting attempt has been made by M. P. Brus to characterize feminine personal nouns according to their historical, lexical, word-formative and stylistic aspects, as well as in the plane of ethnolinguistic, sociolinguistic, linguo-areological, and linguo-culturological phenomena, and to select a feminitive subsystem in the lexical system of the language (Brus, 2019). Many works have been based on identifying the peculiarities of the creation and functioning of feminine personal nouns in modern Ukrainian (Naval'na, 2011, pp. 187-194). The study of feminitives based on the material of several languages has not been overlooked. In particular, H. Błaszkowska focused on such nouns in German and Polish, studying them from the point of view of feminist language criticism (Błaszkowska, 2016). 
W. P. Sosnowski, \& J. Satoła-Staskowiak (Sosnowski \& Satoła-Staśkowiak, 2019) identified the common and distinctive features of Bulgarian, Polish and Russian feminine personal nouns.

\title{
2 Ukrainian neo-feminitives: The problem of perception and the scope of extension
}

Ukrainian feminitives can be conditionally divided into two groups: the first group includes those feminitives that are now perceived as established units approved by language practice. They have survived since the time of Proto-Slavic linguistic unity and the ancient Ukrainian and Old Ukrainian periods. The second group consists of the most recent feminitives, the emergence of which is associated with a number of external factors, including the democratization of society, the emergence of new professions, the more active position of women in Ukrainian society, the expansion of women's professional activities, women holding leadership positions that used to be the sole preserve of men, etc. (Naval'na, 2011, pp. 187-188). The lexical items in the first group do not provoke such heated discussions as the items the second group. The more recent feminitives are perceived differently. Some researchers see in them artificially created lexical items that have emerged rapidly under the influence of linguistic fashion in order to brighten texts and make them more eccentric. These neo-feminitives are sometimes viewed as being contrary to the nature of the Ukrainian language, violating the morphological and word-formative balance, wholeness, and harmony of a language which is already self-sufficient. This argument is supported by the existence and traditional functioning of the old nouns for job titles and professions in Ukrainian which take the so-called 'female' endings $a / i a$ and a 'male' zero flexion. In non-contextual use, these words are considered to be masculine nouns, whereas in context they are linked to men and women with the help of variable words, for example: holova zboriv skazav [said the chairman of the meeting] and holova zboriv skazala [said the chairwoman of the meeting], kompetentnyi suddia [a competent judge] and kompetentna suddia [a competent female judge].

The opponents of the arguments outlined above (the younger generation, according to observations) approve of the emergence of new feminitive derivatives, explaining their emergence by linguistic dynamics and the close interaction of extralingual and intralingual factors. It is a general truth that there are always different reactions to novelty. Changes are always actively discussed, approved of, and criticized. This is true in the case of the functioning of feminine personal nouns. Relevant considerations in this regard have been expressed by W. P. Sosnowski, \& J. Satoła-Staskowiak:

\begin{abstract}
"In societies with a compelling need to change their existing linguistic structures, change can be observed among language users in the perception of reality and in the understanding of the role of women in modern society. The creation and use of feminitives or, conversely, their avoidance, clearly characterise current social relations and relations between the sexes - their way of reasoning, communication, and attributing characteristics to each other" (Sosnowski \& Satoła-Staśkowiak, 2019)
\end{abstract}

The supporters of neo-feminitives argue for the reasonability of the functioning of these units on the basis of the need to establish gender equality, not only in life, but also in the use of certain nouns to denote females and males. Undoubtedly, such reforms will help to establish some degree of gender balance, which has been disturbed for a long time for a number of reasons. Final conclusions can be drawn later about the relevance / irrelevance, productiveness / unproductiveness, usualness / unusualness and 'lifespan' of specific neo-feminitives in Ukrainian. Real-life communication always makes adjustments, language constantly responds to the demands of society, leaving the necessary in place and rejecting the unnecessary. This reflects the development of language and shows its evolution.

In oral speech there is currently an increase in the functioning of units with a feminine meaning in terms of professional positions and other parameters. Such units can be found in scientific 
and academic papers in regard to the achievements of female researchers, and most of all in mass media texts, which serve as an important indicator of language mobility. Journalists have always sought to be original in the transmission of information, implementing certain guidelines of the communication process. In addition, neo-feminitives contribute to the compression of speech, resulting in economy of language.

\section{The profound semantic interpretation and internal lexico semantic classification of Ukrainian feminitives}

An objective and complete study of feminitives provides a description of them in terms of profound semantic interpretation. In this case, it is better to interpret these units as formal means of expressing an abstract meaning, based on cogitative and speech activity with an emphasis on the ideas of functionalism, anthropocentrism and a communicative-pragmatic purpose. Adherence to these methodological procedures is the basis for the selection of the functional-cognitive category of femininity, which should be analysed in terms of derivatology and semantic syntax, allowing feminine personal nouns to be viewed as elements with certain semantic-syntactic features. This approach is profound and comprehensive, as it deals with the study of feminitives in language in general, rather than in a specific language. Guided by the fact that the latest feminine nouns for professions, positions, ranks, degrees, etc. are derived words, they mainly serve as markers of the word-formative meaning of the subject of action. Such lexical items reflect the compression process of the statement, the pattern of which can be seen in the example: "Nezhinocha" profesiia: yak pratsiuie futbolna komentatorka zi Shveitsarii [A non-traditional profession for women: how a female football commentator (feminitive in Ukrainian) from Switzerland does her job] (www. tsn.ua, 30.07.2019) « "Nezhinocha" profesiia: yak pratsiuie zhinka, yaka komentuie futbolni matchi [A non-traditional profession for women: how female football commentator (feminitive in Ukrainian) works]. The root part of the noun highlighted in the first sentence coincides with the root of the verb predicate in the second sentence, and the suffixes -or-and $\boldsymbol{-} \boldsymbol{k}$ - emphasize, respectively, the semantics of the person performing the action and her feminine gender. The main semantic emphasis may be on the word that is the object in the sentence. In this case, the root of this noun is also represented in the feminitive: Ministerka osvity i nauky Hanna Novosad poskarzhylasia na nekonkurentnu zarplatu v 36 tysiach hryven [The Minister (feminitive in Ukrainian) of Education and Science Hanna Novosad complains about her uncompetitive salary of 36,000 hrn] (www.pravda.com.ua, 20.01.2020) « Zhinka, yaka keruie Ministerstvom osvity $i$ nauky, poskarzhylasia na nekonkurentnu zarplatu $v 36$ tysiach hryven [The woman who runs the Ministry of Education and Science complains about her uncompetitive 36,000 hrn salary]. In Ukrainian linguistics, various transpositional and transformational processes, as a result of which words with the word-formative meaning of the subject of action occurred, have been described in detail by I. R. Vykhovanets (Vykhovanets', 1988, pp. 134-139).

The cognitively oriented category of femininity is clarified by its description in the context of semantic syntax and on the basis of speech, which makes it possible to analyse these feminine personal nouns in accordance with their implementation of the functions of subject, object or addressee, specified in narrower terms considering their relationship to actions, processes, states, etc., and to identify the specifics of women's personal nouns in certain conditions of communication. In addition, it is important to consider the semantic-syntactic relations in which these types of items are united by the general idea of femininity, on condition that they are combined with the prop word. In Ukrainian linguistics, such an algorithm has been implemented in the study of semantic cases (Kostusiak, 2013) and minimal syntactic units (Mezhov, 2012). Thus, these conceptual principles are sufficiently tested and can serve as a basis for the comprehensive study of the latest feminitives. All this contributes to the creation of a semantic-cognitive paradigm, which is structured by grammemes with a narrower categorical meaning - feminitive subjectivity; feminitive objectivity; and feminitive addressant. 
A grammeme of feminitive subjectivity is at the centre of the cognitive-semantic hierarchy of the category of femininity, and it denotes a female person who actively performs any action (physical, locative, mental, speech, etc.) or is a carrier of the process or state: Narodna deputatka Ukrainy Anna Skorokhod, yaku ranishe vykliuchyly z fraktsii "Sluha Narodu", zaiavyla, shcho 28 bereznia yii test na koronavirus pokazav pozytyvnyi rezultat [Ukrainian People's Deputy (feminitive in Ukrainian) Anna Skorokhod, who was previously excluded from the "Servant of the People" party, claimed that on March 28 her test for Covid-19 was positive] (www .zaxid.net, 30.03.2020); Uriadovytsia Hrynevych khoche zmistovno zminyty shkolu i navchaty ditei finansovii hramotnosti [Government official (feminitive in Ukrainian) Hrynevych wants to change the school curriculum profoundly and to teach students financial literacy] (www.sts.sumy.ua, 19.05.2019); Ahentka zniala video pro "naishchaslyvishoho khloptsia na karantyni" [An agent (feminitive in Ukrainian) has recorded a video about "the happiest guy in quarantine"] (www.reazon.live, 12.04.2020); Shveitsarska dyplomatka Haidi Hrau stala novym spetspredstavnykom holovy OBSIe v Ukraini ta u Trystoronnii kontaktnii hrupi [Swiss diplomat (feminitive in Ukrainian) Haidi Grau has become a new Special Representative of the OSCE Chairperson-inOffice in Ukraine and in the Trilateral Contact Group] (www.tyzhden.ua, 5.12.2019). In modern Ukrainian, such nouns are usually implemented by the nominative case, which is formally and syntactically connected (in the form of interdependent bilateral coordination) with the predicate, and with the communicative structure of the statement can implement the topic: Demokratka Pelosi ocholyla nyzhniu palatu Konhresu. Yaki yii plany na stinu Trampa? [Democrat (feminitive in Ukrainian) Pelosi has become the leader of the House of Representatives. What is her opinion of Trump's wall?] (www. bbc.com, 3.01.2019).

More rarely, such nouns are implemented by other cases: 1) the dative: ...18 chervnia 64 richnii kantslertsi Nimechchyny Anheli Merkel stalo pohano na zustrichi z Prezydentom Volodymyrom Zelenskym... [... on June 18 the 64 year-old German Chancellor (feminitive in Ukrainian) Angela Merkel suddenly felt sick during a meeting with President Volodymyr Zelenskyi...] (www.ukranews.com, 27.06.2019); Kantslertsi Nimechchyny Merkel stalo zle pid chas zustrichi $i z$ Zelenskym [The Chancellor (feminitive in Ukrainian) suddenly felt sick during a meeting with President Zelenskyi] (www.tsn.ua, 27.06.2019); 2) the instrumental: Poriad z ukrainskoiu versiieiu tsoho uryvku $v$ arkhivi takozh zberihsia pereklad anhliiskoiu yoho chastyny, zroblenyi arkhymandrytkoiu sester-vasyliianok... [Next to the Ukrainian version of this extract, there is an English translation, done by the Archimandrite (feminitive in Ukrainian) of the Basilian Order...] (www.flibusta.site, 2014); Odnak, skhozhi intsydenty traplialysia $z$ kantslerkoiu $i$ ranishe [However, similar incidents involving the Chancellor (feminitive in Ukrainian) have occured before] (www.znaj.ua, 19.06.2019); 3) the accusative: Kantslerku raptovo zatriaslo. Merkel znovu stalo zle na ofitsiinomu zakhodi [The Chancellor (feminitive in Ukrainian) seen shaking again. Merkel fell ill again during an official meeting] (headline) (www.tsn.ua, 27.06.2019); 4) the genitive: ... u kantslerky nemaie problem zi zdoroviam [...the Chancellor (feminitive in Ukrainian) is in good health] (www.thebabel.com.ua, 10.07.2019).

The formal-syntactic specificity of linguistic units that implement the grammeme of feminitive subjectivity and which are expressed by indirect morphological cases is determined by their role of the adverbial subordinate part of the sentence, combined with the predicate of the one-sided subordinate connection. In typical occurrences, all secondary morphological representatives are components of a complex rheme.

The signs of gender orientation are revealed by language units that mark the grammeme of feminitive objectivity. A profound semantic analysis of such nouns makes it possible to state that they denote a female person as an object of someone's action. Less frequently, these lexical items implement the function of the object of a state or process, mainly emotional or mental. All of these items function as proverbial subordinate members of the sentence and, on the communicative sublevel, a component of the rheme. In modern Ukrainian, a grammeme of feminitive objectivity is represented by the following morphological cases: 1) the accusative as a central mean of expression: U seredu, 30 sichnia, pravookhorontsi zatrymaly mytnu brokerku Olenu Chornu, shcho pratsiu- 
vala u viddili mytnoho oformlennia "Sknyliv" [On Wednesday January 30, authorities arrested customs broker (feminitive in Ukrainian) Olena Chorna, who worked in the 'Skynyliv' customs clearance department.] (www.zaxid.net, 31.01.2019); U Zhytomyri sohodni sud zalyshyv pid vartoiu separatystku, yaka spryiala diialnosti tak zvanii "DNR" [A court in Zhytomyr has ordered a separatist (feminitive in Ukrainian) who was involved in the activities of the so called DPR to be held in custody] (www.unian.ua, 15.11.2019); 2) the genitive: Sud zniav z volonterky Marusi Zvirobii (Oleny Bilenkoi) vsi protsesualni zoboviazannia [The court revoked all preventive measures of volunteer (feminitive in Ukrainian) Marusia Zvirobii (Olena Bilenka)] (www . hromadske .ua, 8.05.2020); 3) the instrumental: Damy u chornomu: Anhela Merkel zustrilasia z novoiu premierministerkoiu Finliandii [Ladies in black: Angela Merkel meets new Finnish Prime Minister (feminitive in Ukrainian)] (headline) (www.tsn.ua, 19.02.2020); Vodnochas, yak povidomyv Riaboshapka, yomu ne vdalosia "diishly zghody shchodo vsikh elementiv domovlenosti" z advokatkoiu [At the same time, as Riaboshapka stated, he could not come to an agreement with a lawyer (feminitive in Ukrainian) about all the details] (www.hromadske.ua, 6.11.2019).

Occasionally, a contamination of objective and locative semantics can be observed, which emphasizes a reference locative predicate with the meaning of movement or transition in space: DBR pryishlo iz obshukom do kolyshnoi narodnoi deputatky [SBI (State Bureau of Investigations) has searched a house of a former People's Deputy (feminitive in Ukrainian)] (www.zik.ua, 10.04.2020).

The least semantic and morphological branching is inherent in the grammeme of feminitive addressant, the purpose of which is to denote females for whose benefit or harm someone acts. They are in adverbial connection with the prop verb, in particular its form of connection. In Ukrainian, the feminitives of this group are implemented by the morphological dative case: Advokattsi rodyn zahyblykh na Maidani Zakrevskii proponuvaly ocholyty vidpovidnyi departament v HPU [Zakrevska, a lawyer (feminitive in Ukrainian) who represents families of activists killed during the Maidan protests in Kyiv, was offered a head position in a certain department of the PGOU (Prosecutor General Office of Ukraine)] (www.hromadske.ua, 6.11.2019); DBR povidomylo pro pidozru eksdeputattsi Chornovol [SBI (State Bureau of Investigations) have informed a former deputy, (feminitive in Ukrainian), Chornovol that she is suspected of committing a crime] (headline) (www.tyzhden.ua, 25.02.2020); U Lutsku riatuvalnyky MNS dopomohly hazetiartsi potrapyty na roboche mistse [In Lutsk, rescue workers from the Ukrainian Ministry of Emergencies helped a female newspaper journalist (feminitive in Ukrainian) to get to work] (www.VIP.volyn.ua, 10.01.2011); Kolyshnii holova Zakarpatskoi ODA Hennadii Moskal poradyv chynnii ministertsi osvity Hanni Novosad ne robyty velykoi kilkosti pomylok, koly vona pyshe u sotsialnykh merezhakh [The former head of the Zakarpatska OSA (Oblast State Administration), Hennadii Moskal, warned current Minister (feminitive in Ukrainian) of Education Hanna Novosad to avoid making mistakes on social media] (www.zik.ua, 12.02.2020).

The addressant-objective dichotomy is implemented by the prepositional-case form of the instrumental case: Za ministerkoiu oborony Nimechchyny zalyshyly stupin doktora nauk [The German Minister (feminitive in Ukrainian) of Defence keeps her Doctorate degree] (headline) (www.dw.com, 9.03.2016).

The three grammemes of feminitive subjectivity, feminitive objectivity, and feminitive addressant are related by neo-positive differences, as their generalized semantics are structured by narrower meanings that simultaneously have common and immanent features, allowing for the comparison of these three grammatical meanings. Each grammeme of the functional-cognitive category of femininity is implemented by nouns in certain cases, among which one has the status of the primary form, and the others function as its equivalents. This aspect helps to identify the features of the Ukrainian language.

The lexico-semantic differentiation of modern feminitives has a lower degree of versatility and generalization. They most often refer to females according to profession or type of activity in the following fields: 1) politics: Prezydentka Hruzii Salome Zurabishvili pomyluvala dvokh vidomykh opozytsioneriv, chyie uviaznennia na Zakhodi nazyvaly politychnymy [The President (feminitive 
in Ukrainian) of Georgia Salome Zurabishvili has pardoned 2 well-known opposition politicians whose imprisonment western countries viewed as political] (www.pravda.com. ua, 15.05.2020); Naimolodsha premierka u sviti: khto taka Sanna Marin z Finliandii? [The youngest Prime Minister (feminitive in Ukrainian) in the world: who is Finland's Sanna Morin?] (www.dw.com,10.12.2019); Kantslerka Nimechchyny Anhela Merkel, yaka perebuvaie $v$ karantyni $z$ vechora nedili, zdala test na koronavirus [German Chancellor (feminitive in Ukrainian) Angela Merkel, who has been under quarantine since Sunday evening, was tested for Covid-19] (www.volyn.com.ua, 23.05.2020); Hromada Kalushchyny proty toho, shchob raionnoiu osvitoiu keruvala "rehionalka" [The community of Kalushchyna is against the appointment of a regional politician (feminitive in Ukrainian) as the head of the district education department] (www.kurs.if.ua, 6.02.2019); Svobodivka Babinska rozzhylas novoiu nerukhomistiu u Zolochevi [Svobodivka (the name of a political party in Ukraine and a Ukrainian feminitive) Babinska acquires a new property in Zolochiv] (www.varianty.lviv.ua, 22.08.2019); 2) finance, economics and trade: ... a za vyruchkoiu shchodenno prykhodyla inkasatorka $v$ suprovodi dvokh cholovikiv [... cash messenger (feminitive in Ukrainian), accompanied by two men, came daily for revenues] (www.Ionckoho.lviv.ua, 15.05.2019); Zatrymaly nepovnolitniu dylerku z Okhtyrky [A minor dealer (feminitive in Ukrainian) from Okhtyrka has been arrested] (www.odindoma. sumy .ua, 20.05.2020); 3) law: Advokatka "zaminuvala" desiatky sudiv [Lawyer (feminitive in Ukrainian) "mined" dozens of courts] (headline) (www.ukrreporter.com.ua, 14.02.2020); Kolomyiska notariuska rozpovila pro protseduru prostavlennia apostyliu [Notary (feminitive in Ukrainian) from Kolomyia informed of imprinting of Apostille stamp] (www.typical.if .ua, 18.05.2020); 4) transport: Dyspetcherka Odeskoi zaliznytsi dopomahala krasty zerno z vahoniv, vlashtuvavshy potiaham dodatkovu zupynku [A dispatcher (feminitive in Ukrainian) of the Odesa railway aided the theft of seeds from wagons by assigning additional stops for trains] (www.silahromad.com.ua, 1.01.2020); 5) art: Oksana Lyniv - odna $z$ trokh naikrutishykh dyryhentok svitu, holovna $v$ operi mista Hrats [Oksana Lyniv is one of the three greatest conductors (feminitive in Ukrainian) in the world. She is the lead conductor of the Graz Opera] (www.slukh.media, 22.10.2019); Kolomyiska mystkynia Natalia Dovhaniuk pidtrymala konkurs maliunkiv vid BF "Pokuttia" [An artist (feminitive in Ukrainian) from Kolomyia, Natalia Dovhaniuk, has supported a drawing competition from the Charitable Foundation "Pokuttia"] (www.dzerkalo.media, 12.04.2020); 6) education and science: Pedahohynia ta diiachka diaspory Vira Andrushkiv stala pochesnym doktorom universytetu $v$ Lvovi [Teacher (feminitive in Ukrainian) and member of the Ukrainian diaspora Vira Andrushkiv has received an honorary doctorate from the University of Lviv] (www.ukrinform. ua, 28.07.2019); Amerykanska naukovytsia doslidyla teksty Starodavnoho Yehyptu ta vyiavyly, shcho yehyptiany mohly uiavliaty nebo yak zaliznu posudynu [An American scientist has (feminitive in Ukrainian) studied the texts of Ancient Egypt and has discovered that the Egyptians believed that the sky was an iron vessel] (www.hromadske.ua, 7.05.2020); Pro osoblyvosti liudei, narodzhenykh pid znakom Tiltsia, rozpovila vidoma rivnenska astrolohynia Iryna Kravets [Well-known astrologist (feminitive in Ukrainian) Iryna Kravets from Rivne talk about the personality traits of people born under the Taurus star sign] (www.7dniv.rv.ua, 20.04.2020); Istorykynia Iryna Yavorska $z$ Chernivtsiv rozpovila "Hromadskomu radio" pro korotkochasnyi yevreiskyi renesans u Chernivtsiakh pislia zakinchennia Druhoi svitovoi viiny [Historian (feminitive in Ukrainian) Iryna Yavorska from Chernivtsi told "Public Radio" about the short-lived Jewish Renaissance in Chernivtsi after World War II] (www.uajs.org.ua, 1.05.2020); 7) medicine: Yak pravylno nosyty masky, rozpovidaie terapevtka Mariia Krapyvner [How to wear a face mask properly, explained by physician (feminitive in Ukrainian) Mariia Krapyvner] (www.ukropen.net, 2.04.2020); 8) media and publishing: Lutska mediinytsia Kateryna Dulapchii rozpovila pro svoie davnie zakhoplennia ta novu diialnist [Journalist (feminitive in Ukrainian) Kateryna Dulapchii from Lutsk talk about her long-term hobby and a new activity] (www.volyn.tabloyid.com, 10.03.2020); Yana vpershe sprobuie sebe $v$ roli sportyvnoi komentatorky y, zvisno, trokhy khvyliuietsia [Yana will be a sports commentator (feminitive in Ukrainian) for the first time, and, of course, she is a little nervous] (www.tv.suspilne.media, 29.11.2019); Drukovanu ploshchu hazetiarka maie 
nadaty dlia publikatsii ofitsiinoi informatsii Koziatynskoi miskoi rady, yii vykonavchykh orhaniv [Journalists must publish all official information of Koziatyn town council and its executive bodies] (www.vn.depo.ua, 12.12.2019); 9) Karantyn karantynom, a liudei hoduvaty treba, - fermerka z Yavorivshchyny ["Quarantine is quarantine, but people need something to eat", said a farmer (feminitive in Ukrainian) from Yavorivshchyna] (www.propozitsiya.com, 21.03.2020); 11) modelling and fashion: Frankivska modelierka dva tyzhni pidkoriala hruzynski hory [A fashion designer (feminitive in Ukrainian) from Frankivsk spent two weeks climbing mountains in Georigia] (www.kurs.if.ua, 20.03.2019); 12) social and public activities: Volonterka spilky afhantsiv Volynskoi oblasti Halyna Tsvyd prosyt doluchytys do poriatunku vid khvoroby yii ridnoho brata Volodymyra [A volunteer (feminitive in Ukrainian) of the Afghan association from the Volyn region, Halyna Tsvyd, has asked for help in saving her brother Volodymyr's life] (www . volynpost .co, 20.05.2020).

Feminitives are also used to denote women who have obtained a certain academic degree: Doktorka medychnykh nauk povidomyla, shcho koronavirus zdebilshoho prokhodyt bez uskladnen [A doctor (feminitive in Ukrainian) of Medical Science has stated that in most cases Covid-19 does not cause any complications] (wz.lviv.ua, 19.03.2020); heads of institutions, organizations, and educational institutions: Kerivnytsia EGOV4Ukraine pro vazhlyvist e-uriaduvannia v Ukraini $v$ umovakh pandemii [The head (feminitive in Ukrainian) of EGOV4Ukraine on the importance of a government in Ukraine during the pandemic] (headline) (www . euukrainecoop.net, 29.04.2020); Yaponska shefynia Yuki Chizui (Yuki Chidui) z 2010 roku ocholiuie sushi-restoran Nadeshiko Sushi $v$ Tokio [Japanese chef (feminitive in Ukrainian) Yuki Chidui has run the Nadeshiko Sushi restaurant in Tokyo since 2010] (www.posteat.ua, 1.10.2019); U Kropyvnytskomu na "hariachii linii" miskoho holovy cherhuvatyme nachalnytsia upravlinnia osvity Larysa Kostenko [In Kropyvnytskyi the head (feminitive in Ukrainian) of the education department, Larysa Kostenko, will be on call on the mayor's "hotline"] (www.rk.kr.ua, 4.05.2020); Rektorka Zakarpatskoho uhorskoho instytutu im. Ferentsa Rakotsi II Ildyka Oros sklala povnovazhennia kerivnyka vyshu [Ildico Orosz has resigned fro, her post as rector (feminitive in Ukrainian) of the Ferenc Rakoczi II Transcarpathian Hungarian College of Higher Education] (www.pmg.ua, 20.03.2020); Utim, prorektorka Sofiia Opatska radyt ne perepratsovuvaty ta berehty syly dlia vykonannia inshykh oboviazkovykh zavdan [But vice-rector (feminitive in Ukrainian) Sofiia Opatska recommends not overworking and saving energy for other important tasks] (www. ucu.edu.ua, 24.03.2020); the winners of various competitions and awards: Oksana Hordiienko - dyplomantka II etapu Vseukrainskoi olimpiady zi spetsialnosti "Zhurnalistyka" [Oksana Hordienko has won a diploma (feminitive in Ukrainian) in stage II of the All-Ukrainian Olympiad in Journalism] (www.pnpu.edu .ua, 23.03.2019) etc.

Occasionally, women's nominations reflect a tendency towards certain actions and behaviour, including risky and dishonest actions: Avantiurnytsia povernula nahrabovane $i$ yii, yak matir dvokh ditei, vidpustyly na voliu [The thief (feminitive in Ukrainian) returned the stolen items and, as a mother of two children, was released] (www.ntn.ua, 25.03.2019).

\section{The regularities of creation and the problems of codifica- tion of new feminitives in Ukrainian media texts}

In modern mass communication, various suffixes are used in order to express the gender of feminine personal nouns. The most productive of these suffixes is $\boldsymbol{k}(a)$. The active creation of new lexical items with the help of this formant is quite natural in Ukrainian and does not violate tradition. The authors of the new edition of Ukrainian Orthography advise giving preference to it. (Ukraïns'kyı pravopys, 2019, p. 27): Investorka vklala v prydbannia kvartyry ostanni hroshi, ale zhytla dosi tak $i$ ne otrymala [An investor (feminitive in Ukrainian) put the last of her money in purchasing an apartment, but still has no place to live] (www.stopcor.org, 3.02.2020); Narodzhena v Ukraini brytanska prodiuserka otrymala "Oskara" za naikrashchyi korotkyi dokumentalnyi film [An Ukrainian-born British filmmaker (feminitive in Ukrainian) has received an Oscar for 
Best Documentary (short subject)] (www.ukrainian.voanews.com, 10.02.2020); Pomerla latviiska parlamentarka, druh Ukrainy Yuta Strike [Juta Strike, Latvian parliamentarian (feminitive in Ukrainian) and a friend of Ukraine, has passed away] (www.ukrinform.ua, 18.03.2020); Prylady dlia vymiriuvannia radiatsii vykhodyly z ladu — likvidatorka avarii na ChAES [Instruments for detecting and measuring ionizing radiation failed, said Chernobyl nuclear disaster liquidator (feminitive in Ukrainian)] (www.t1news.tv, 26.04.2020).

In terms of frequency of use, such feminitives are less frequent than derivatives with the suffix -yts-(ia), which forms feminine personal nouns corresponding to the stems - en, ets of masculine nouns: Na Chernihivshchyni zatrymaly posadovytsiu, yaka vymahala khabar [An official (feminitive in Ukrainian) from Chernihivshchyna, who demanded a bribe has been arrested] (www.mynizhyn.com, 20.01.2020) (masculine posadovets [official]). Based on quantitative indicators, units with the suffix $-\boldsymbol{y n}$-(-ia-), which according to the recommendations of Ukrainian Orthography should be added if the base of the masculine equivalent is completed by the suffix ets or consonant, can be included in this group (Ukraïns'kyı pravopys, 2019, p. 27): Fakhivchynia systemy BPD dopomohla kliienttsi ponovytys na roboti ta stiahnuty 185 tys hrn zarobitnoi platy za chas vymushenoho prohulu [A legal aid specialist (feminitive in Ukrainian) has helped a client to get back to work and get a refund of 185,000 hrn for the period of enforced absence] (www.kompanievska-selrada.gov.ua, 20.05.2020); Vydavchynia onlain-media bit.ua ta zasnovnytsia proiektu Kind Challenge Tetiana Hrynova stala brend-ambasadorkoiu filmu "PULS" [The publisher (feminitive in Ukrainian) of online media bit.ua and the creator of Kind Challenge project, Tetiana Hryniova, has become a brand ambassador for the film "PULSE"] (www.kinorob.com, 20.02.2020); Kropyvnytska kinolohynia: sobaka - vidpovidalnist ta dorohe zadovolennia [Cynologist (feminitive in Ukrainian) from Kropyvnytskyi: a dog is an expensive luxury and a responsibility] (www.rk.kr.ua, 27.11.2019).

The ongoing process of adapting new feminitives to the Ukrainian-language paradigm demonstrates the existence of parallel forms created by the formants $-\boldsymbol{k}-(a)$ and $\boldsymbol{y n}(i a)$ : Vidoma fotohrafka $z$ Lutska Anastasiia Aloshyna neshchodavno provela svoiu pershu onlain-fotosesiiu [A well-known photographer (feminitive in Ukrainian) from Lutsk Anastasiia Alioshyna has done her first online photoshoot] (www.volyn.tabloyid.com, 19.05.2020) and Ukrainska fotohrafynia Yuliia Poliashchenko, svitlyny kotroi mozhna pobachyty u zhurnalakh Vogue ta Dazed, rozpovila pro svoi plany [Ukrainian photographer (feminitive in Ukrainian) Yuliia Poliashchenko, who works for Vogue and Dazed, talk about her future plans] (www.nachasi.com, 20.05.2020). Both options employed by journalists correspond to the established patterns of creation.

In an effort to maintain a gender-linguistic balance, journalists sometimes use feminitives that are destructive and contradict the word-formative norms of Ukrainian. In particular, the use of feminine personal nouns with the suffix $-s h$ - is seen as a violation. Their functioning can be explained by the long process of russification experienced by Ukrainians: Yake to znachennia vkladaiut u slovo dyrektorsha... [What a meaning the word directress has...] (www.mediakolo.sumy.ua, 28.08.2019); Naistarsha barmensha na planeti pomerla u Velykobrytanii .. v v hrafstvi Bakinhemshyr $v$ tsentri Anhlii [The oldest bartender (feminitive in Ukrainian) in the world has passed away in Buckinghamshire, Great Britain] (www.styknews.info, 28.02.2019); V Uzhhorodi vpiimaly sutenershu [A Pimp (feminitive in Ukrainian) has been arrested in Uzhhorod] (www.mukachevo.net, 12.02.2018). It would be more correct to replace the selected lexical items with dyrektorka [directress], barmenka [bartender], sutenerka [pimp]. Occasionally, journalists overlook the fact that the suffix $-\boldsymbol{y s}$ - $(i a)$ is rarely used and they use it to form feminine words: Vsiu nich pysala stsenarii zi slovnykom. Shcho skazhe redaktrysa? [I have been writing a script using a dictionary. What will the editor (feminitive in Ukrainian) say about this?] (www svatove.city, 26.08.2018); Os i "inspektuvannia inspektoriv" - tobto perevirka chynovnytseiu miskoho rivnia - teper na vulytsi Verkhovynnii, pereviriatyme inspektrysa Yeliena Vladislavovna Bolshinskaia [Here is "inspection of inspectors" - a revision by an official — now inspector (feminitive in Ukrainian) Yeliena Vladislavovna Bolshinskaia inspects on Verkhovynna Street] (www.glupov .net, 20.05.2020). However, it is considered natural for Ukrainian to have cognate lexical items to the 
selected words using the formant $k$ : redaktorka [editor], inspektork $a$ [inspector].

Pro-feminist journalists sometimes use compound nouns, which are codified in terms of both derivational and spelling features (they are quite reasonably written with a hyphen). Such lexical items can be divided into two groups: 1) items with two feminine personal nouns: Kolyshnia khostes i barmenka-kasyrka: merezhu zdyvuvala nova pomichnytsia Shmyhalia [Former hostess and bartender-cashier (feminitive in Ukrainian): media surprised by Shmyhal's new assistant] (www.shlyahta.com.ua, 14.04.2020); "Tse zalezhyt vid stanu patsiienta, vid yoho viku i vid tsiloho riadu prychyn. A pro tse liudy chasto zabuvaiut", - zauvazhyla likarka-terapevtka [It depends on a patient's condition, age and other factors. People often forget about that, said a physician (feminitive in Ukrainian)] (www.golovnatema.kanalukraina.tv, 28.04.2020); Frankivska nardepka-"svobodivka" Oksana Savchuk zaiavyla pro stvorennia mizhfraktsiinoho deputatskoho obiednannia u Verkhovnii Radi [People's Deputy and svobodivka (name of political party in Ukraine and Ukrainian feminitive) from Frankivsk, Oksana Savchuk, commented on the creation of an inter-party deputy association in the Verkhovna Rada] (www . chesno.org, 25.09.2019); U RF vidkryly spravu proty profesorky-infektsionistky [In the Russian Federation, the case against an infectious disease specialist (feminitives in Ukrainian) has opened] (www.gordonua.com, 23.03.2020); 2) items with one part formed on the model of a feminine personal nouns, and the other part formed on the model of a masculine personal noun: Na Rivnenshchyni deputatka-likar bezkoshtovno konsultuvatyme liudei v onlain-rezhymi [A deputy doctor (feminitives in Ukrainian) from Rivnenshchyna will consult online for free] (www.rivnenews.com.ua, 25.03.2020). In the sample material there are not as many language units of the second group as there are of the first, indicating a tendency to establish gender balance.

Occasionally, a compound feminitive is structured by two parts, one of which occurs as a result of transcribing an English lexical item: Vinnytska polisvumen robytyme reidy $v$ SIZO, aby peresvidchytys $v$ dotrymanni prav uviaznenykh [A policewoman from Vinnytsia will be raiding pretrial detention facilities to ensure that the rights of detainees are respected] (www.vn.depo.ua, 22.07.2016). Functioning in Ukrainian, the selected unit reveals a formal permanence: "Taka robota - tse mriia moho zhyttia". Interviu $z$ chernivetskoiu polisvumen ["This job is a dream". An interview with a policewoman from Chernivtsi] (headline) (www.0372.ua, 17.04.2016).

The use of several neo-feminitives in one sentence shows the modernization of media texts and the intensification of feminitive use: Andrii Hordieiev pryvitav druzhyn i materiv viiskovosluzhbovtsiv, zhinok-volonterok ta hromadskykh diiachok [Andrii Hordieiev congratulated the wives and mothers of military personnel, female-volunteers (feminitive in Ukrainian) and public figures (feminitive in Ukrainian)] (www.khoda.gov.ua, 7.03.2019); Movoznavytsia $i$ politykynia Iryna Farion prezentuvala $v$ Uzhhorodi svii naukovyi dorobok [Linguist and politician (feminitives in Ukrainian) Iryna Farion presented her academic works in Uzhhorod] (www.mediacenter. uzhnu.edu.ua, 13.11.2019); Hinekolohynia, politykynia ta psykholohynia: yak teper nazyvatymut ternopolianok. A vy shcho dumaiete? [Gynecologist, politician and psychologist (feminitives in Ukrainian): how to name women's job titles in Ternopil. What do you think?] (www.te.20minut.ua, 16.12.2019); Proekt "Slava Ukrainy". Pro Olenu Pchilku - ukrainsku pysmennytsiu, etnohrafyniu $i$ folklorystku, vydavchyniu, redaktorku... [Project "Glory to Ukraine". About Olena Pchilka - Ukrainian writer, ethnographer and folklorist, publisher, editor (feminitives in Ukrainian)...] (www.golos.com.ua, 17.07.2019).

\section{Summary}

The latest feminine personal nouns for professions, job titles, and other activities, form part of the lexico-semantic system of Ukrainian and, at the same time, are an indication of its continuous dynamics. These neo-derivatives are actively used in modern Ukrainian media texts, contributing to the modernization and liberalization of the text, and the creation of gender-linguistic balance. It is no less important that these lexical items are now codified in the new edition of Ukrainian 
Orthography (Ukraïns'kyı pravopys, 2019, p. 27). These arguments and the focus on bilateral interpretation (semantics as dominant and formal), as well as in the context of anthropocentrism and active communication, form the basis for the establishment of the functional-cognitive category of femininity. Research in terms of derivatology and semantic syntax make it possible to consider feminine personal nouns as elements with certain semantic-syntactic features, representing a profound and comprehensive aspect of the research. It is supplemented by the lexico-semantic classification of these units. The specifics of Ukrainian feminitives are revealed by a detailed study of the means of expressing femininity - suffixes and case forms of feminine personal nouns - and their codified use. This set of features serves as a basis for the interpretation of the category of femininity as an abstract concept that generally denotes units with the meaning of feminine gender and combines three grammemes with a narrower categorical meaning - feminitive subjectivity; feminitive objectivity; and feminitive addressant - which form a certain hierarchy and semanticcognitive paradigm. Despite the codification and explanation of the derivational features of the studied nominations in the new edition of Ukrainian Orthography (Ukrä̈ns'ky̆ pravopys, 2019, p. 27), the newly formed language units still require professional analysis and recommendations.

\section{References}

Arkhanhel's'ka, A. M. (2013a). Do problemy slovotvirnoï feminizatsï v ukraïns'kiǔ movi novitn'ö̈ doby: Tradytsiia i suchasnist'. Movoznavstvo, 2013(6), 27-40.

Arkhanhel's'ka, A. M. (2013b). Neofeminatyvy v novitniı̌ ukraïns'kiı̌ movi: Leksykohrafichnyı̌ i transliatolohichnyı aspekt. Aktual'ni pytannia suchasnoï filolohï: Movoznavchi studiï: Zbirnyk naukovykh prats', $21(3), 59-64$.

Arkhanhel's'ka, A. M. (2014a). Do problemy slovotvirnoï feminizatsiï v ukraïns'kiŭ movi novitn'oï doby: Tradytsiia i suchasnist'. Movoznavstvo, 2014(1), 58-70.

Arkhanhel's'ka, A. M. (2014b). Femininni innovatsiï v novitn'omu ukraïns'komu nazovnytstvi. Movoznavstvo, 2014(3), 34-50.

Bilaniuk, L. (2003). Gender, language attitudes and language status in Ukraine. Language in Society, 32(1), 47-78. https://doi.org/10.1017/S0047404503321037

Błaszkowska, H. (2016). Weibliche Personenbezeichnungen im Deutschen und Polnischen aus der Sicht der feministischen Sprachkritik. Wydział Neofilologii UAM w Poznaniu. https://doi.org/10.14746/ 9788394601737

Brus, M. P. (2019). Feminityvy v ukrä̈ns'kǐ movi: Heneza, evoliutsiia, funktsionuvannia: Monohrafiia (Pt. 1). Derzhavnyı̌ vyshchyı̌ navchal'nyı̌ zaklad "Prykarpats'kyı̌ natsional'nyı̌ universytet imeni Vasylia Stefanyka".

Cameron, D. (1992). Feminism and linguistic theory. Palgrave Macmillan. https://doi.org/10.1007/ 978-1-349-22334-3

Fedurko, M. I. (2010). Slovotvirna morfonolohiia ukraïns'kykh feminatyviv u linhvokul'turolohichnomu aspekti. In I. A. Karpilovs'ka \& N. F. Klymenko (Eds.), Vidobrazhennia istorï ta kul'tury narodu $v$ slovotvorenni: Dopovidi XII Mizhnarodnoï naukovoï konferentsï Komisï zi slov'ians'koho slovotvorennia pry Mizhnarodnomu komiteti slavistiv (pp. 433-442). Vydavnychyı̌ dim Dmytra Buraho.

Guzaerova, R., Sabolová, D., \& Kosova, V. (2018). Russian feminine nouns with suffix $-k(a)$ in the modern mediaspace. Revista San Gregorio, 2018(25), 37-42.

Karwatowska, M., \& Szpyra-Kozłowska, J. (2010). Lingwistyka płci: Ona i on w języku polskim. Wydawnictwo Uniwersytetu Marii Curie-Skłodowskiej.

Kostusiak, N. M. (2013). Morfolohichni ta semantychni vidminky suchasnoï ukraïns'koï literaturnoï movy. Ukraïns'ka mova: Nauk.-teoret. zhurn. Instytutu ukraïns'koï movy NAN Ukraïny, 2013(4(48)), 45-57.

Kubiszyn-Mędrala, Z. (2007). Żeńskie nazwy tytułów i zawodów w słownikach współczesnego języka polskiego. Ling Varia, 2(1), 31-40.

Litosseliti, L., \& Sunderland, J. (2002). Gender identity and discourse analysis. John Benjamins Publishing Company. https://doi.org/10.1075/dapsac.2

Mezhov, O. H. (2012). Typolohiia minimal'nykh semantyko-syntaksychnykh odynyts'. Volyns'kyı̆ natsional'nyı̆ universytet imeni Lesi Ukraïnky. 
Mills, M. H. (1999). Slavic gender linguistics. John Benjamins Publishing Company. https://doi.org/ 10.1075/pbns. 61

Naval'na, M. I. (2011). Dynamika leksykonu ukraïns'kö̈ periodyky pochatku XXI st. Vydavnychyı̆ dim Dmytra Buraho.

Poda, O. I. (2008). Feminityvy i maskulinityvy iak henderni markery zhurnal'nykh zaholovkiv u konteksti hendernoï polityky zakhidnoukraïns'kykh chasopysiv dlia zhinok. Derzhava ta rehiony: Humanitarni nauky: Naukovo-vyrobnychy̆ zhurnal, 2008(3), 120-126.

Redko, Y. (2016). Feminitives in the Ukrainian argot: Attempt of complex analysis. Argotica, 5, $155-170$.

Sosnowski, W. P., \& Satoła-Staśkowiak, J. (2019). A contrastive analysis of feminitives in Bulgarian, Polish and Russian. Cognitive Studies / Études cognitives, 2019(19), Article 1922. https://doi.org/ $10.11649 / \mathrm{cs} .1922$

Ukraïns'kyı pravopys. (2019). Ministerstvo osvity i nauky Ukraïny. https://mon.gov.ua

Vykhovanets', I. R. (1988). Chastyny movy v semantyko-hramatychnomu aspekti. Naukova dumka.

Weatherall, A. (2003). Gender, language and discourse. Routledge. https://doi.org/10.4324/ 9780203988817

Zahnitko, A. P. (1987). Koreliatyvnist' imennykiv-nazv osib cholovichoho i zhinochoho rodu. Ukraïns'ke

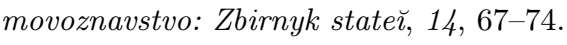

The publication was financed at the authors' expense.

The authors declare that they have no competing interests.

All the authors participated equally in preparing conception and academic editing of this article.

This is an Open Access article distributed under the terms of the Creative Commons Attribution 3.0 PL License (http://creativecommons.org/licenses/by/3.0/pl/), which permits redistribution, commercial and noncommercial, provided that the article is properly cited.

(C) The Authors 2020

Publisher: Institute of Slavic Studies, Polish Academy of Sciences

Publishing History: Received 2020-06-10; Accepted 2020-07-21; Published 2020-12-23. 